\title{
Relationship Between Playing Environment and Parenting With Motor Skills Kindergarten
}

\author{
Anton Komaini $^{1 *}$, Mohd. Ekhsan Maulana Sadikin ${ }^{1}$
}

\author{
Faculty of Sport Sience, Universitas Negeri Padang, Indonesia \\ *Corresponding author. Email: antonkomaini9@gmail.com
}

\begin{abstract}
Based on the author's observations in the field, it shows that there are still many kindergarten students whose fundamental motor skills are still low. This study aims to explain the Relationship between playing environment and parenting with motor skills kindergarten students Pertiwi 2 Air Tawar Padang, individually or together. This type of research is correlational. The study population was 32 students of Pertiwi II Kindergarten. Sampling in this study was conducted with a purposive sampling technique of 18 people. Data collected using tests on all three variables. Variable data of gross motor skills were taken using gross motor tests, playing environment variables using questionnaires and parenting parents also by using questionnaires. Data analysis techniques are product-moment correlation, and multiple correlation. The results of data analysis showed that: 1) There was a significant relationship between the playing environment towards the gross motoric development of Pertiwi II Kindergarten students with thit $=1.77>$ ttab $=1.75$. 2) There is a significant relationship between parenting towards gross motoric development of Pertiwi II kindergarten students with tcount $=$ 2.60> ttab $=1.75,3)$ There is a jointly significant relationship between the playing environment and parenting style towards development gross motoric students of TK Pertiwi II with F count $=6.65>$ Ftable $=3.68$.
\end{abstract}

Keywords: Playing Environment, Parenting, Motor Skills

\section{INTRODUCTION}

Sports can also be used for the development of technology that is useful in supporting the sport itself. Another benefit that is not less important than the above is for health and human development itself. This is in accordance with the Law of the Republic of Indonesia Number 3 of 2005 Chapter II concerning the basis, functions and objectives of Article 4, which reads: National sports aim to maintain and improve health and fitness, achievement, human quality, instill moral values and nobility, sportsmanship, discipline, strengthen and foster national unity and integrity, strengthen national resilience, and uplift the dignity and honor of the nation ".

Sports which is a physical, physical activity that is very beneficial for human development, especially at the age of children. At the age of children (1-6 years) is the best time to develop the development of a child's physical-motor abilities. Activities such as walking, running, jumping, jumping are activities that can support the development of a child's motor development. "at the age of children they will continue to hone their gross motor skills such as jumping, climbing, running, catching and kicking the ball" [1]. The basic motion can be done both indoors and outdoors. However, every activity carried out has different benefits and advantages. "Children's play activities can be done both indoors and outdoors. These two places are equally important but have different benefits " [2]. The development of a child's gross motor skills is also influenced by various other factors that are thought to be able to inhibit these developments, such as the social environment, parenting, children's nutrition. "Motor development is not a passive process where the gene determines the refinement of the sequence of skills over time" [3]. Conversely, children actively develop skills to achieve goals within the limits determined by the child's body and environment. Children and the environment, together work together as part of a system that continues to change Environment and several other factors are also very influential on children's development. "Child growth and development is influenced by the genetic makeup of children and the daily environment, which includes care, medical care, and the opportunity for children to learn various kinds of skills that are evidence of progress the welfare of each child depends on mastering certain skills in the six areas of development (a) physical, (b) motoric, (c), perceptual, (d) cognitive, (e) language, (f) personalsocial" [4]. playground environment expressed by [5], mentions:

\section{Playing at school}

In some ways playing at school is different from playing at home. Usually in schools there is a greater chance of playing in groups compared to groups playing at home. The game material is much different because generally children do not have a large number of playing tools such as those available at school.

\section{Play indoors}

Playing indoors is usually a little quieter and the room is wider because the room for play is usually designed and arranged so that it can be used for a variety of activities.

\section{Outdoor play}

Playing outdoors usually creates more noise and requires strength and more enthusiasm. Playing outdoors requires a wide location for children to run, jump, and ride. Playing on a grassy yard or the presence of sand is not too dangerous compared to the floor in a generally harder room. Affects the balance of the child's development. 
needs such as physical needs, psychology and learning cannot be separated. Fulfilling the physical needs of children but not paying attention to their psychological needs will result in developmental problems. Likewise, vice versa, a child whose physical needs are often overlooked experiences problems in learning and dealing with others. Meeting the basic needs of children in all fields can increase their chances of developing their potential.

Parenting also has several dimensions that are applied to a child. Parenting has two dimensions, namely the dimensions of control and dimensions of warmth. In addition to that, parenting parents also have a variety of parenting styles that are sometimes applied by parents. The control dimension has five musty, namely, (a) restrictions, (b) demands, (c) strict attitude, (d) interference, (e) arbitrary power. While the warmth dimension has 5 aspects, namely, (a) parental attention, (b) parental responsiveness to the needs of the child, (c) spending time together, (d) showing attitudes antusia on behavior displayed by the child, (e) sensitive to children's emotional needs ".Motor development is influenced by the brain and sensory system in children. Both of these things determine how a person's motoric development is going forward. Eye and hand coordination, motivation and encouragement to want to do something is the key to success in carrying out a movement. Besides that the environment is also very important for the development of children's motor skills. In other words the environment, namely experience, plays a very important role in the emergence of new motor skills.

\section{METHODOLOGY}

This type of research is correlation research. "Correlation or correlational research". The place of this research was held at TK Pertiwi 2 Air Tawar Barat, Padang. The study was conducted in May-June 2015. The instruments of this study were questionnaires and tests of gross motor skills. "A questionnaire is a number of written questions that are used to obtain information from the respondent in the sense of a report about his personality or other things he knows. This instrument is used to obtain data or information about the playing environment and parenting" [6].

"The instrument used to see the gross motoric abilities of kindergarten students is gross motoric tests which include jumping, walking, running, balance training, throwing, and catching the ball". [7].

The population is all the objects of research. If someone will examine all the elements in the research area, the research is population research. With the above understanding, the population in this study were all students of Pertiwi 2 Kindergarten which numbered 32 people

The population in this study was also added to the parents and this population corresponds to the population of TK Pertiwi 2. This is because parents become representatives in filling out questionnaires or questionnaires about the playing environment and parenting parents.
The total of the total population is 64 people. All of them have been added up between TK Pertiwi 2 and parents who will represent the student in filling out the questionnaire.

Based on the existing population, the researcher took a sample with a purposive sampling technique. Where students are taken who are considered able to assist in this research by considering other matters.

\section{RESULTS}

\section{Description of Research Data}

The data of this study consisted of: gross motor skills as the dependent variable, playing environment and parenting style as independent variables. For each of the variables below, the average values, standard deviations, medians, frequency distributions, and histograms of each variable are presented: (1). Based on the research data for the Play Environment score, the lowest score was 23 and the highest score was 36. From the data analysis the average was 29.44, Standard deviation was 3.31, Median was 29.5 , Mode 32 ; (2). Based on the research data for parenting scores, the lowest score was 23 and the highest score was 36 . From the data analysis, the average was 29.44, Standard deviation was 7.07, Median 37.5, Mode 40; (3). Based on the research data for the score of Rough Motor Ability obtained the lowest score of 12 and the highest score 18. From the data analysis it is known that the average is 17.33 , standard deviation is 1.64 , median is 18.00 , mode 18 .

\section{DISCUSSION}

\section{Playing Environment}

Based on the significance test of the correlation between pairs of playing environment scores with gross motor skills as shown in Table 11 above, it was obtained $\mathrm{t}_{\text {observed }}=1.77>\mathrm{t}_{\mathrm{tab}}=1.75$ at the significance level $\alpha=0.05$. Thus, Ha said that there was a significant relationship between the environment of playing parents towards the gross motoric abilities of students accepted, consequently $\mathrm{H}_{0}$ was rejected. This finding concludes that there is a significant relationship between parents' playing environment towards gross motor skills of students. This means that the better the playing environment, the better gross motor skills.

The playing environment, also known as children's playground, is a place that functions as a physical activity (playing) such as running, jumping, catching, climbing, which is a daily routine. A child needs a decent and safe place to play for playing activities. According to Gusril (2009), that children's play activities can be done both indoors and outdoors.

\section{Parenting}

Based on the significance test of the correlation between pairs of parents' parenting scores with gross motor skills as seen in Table 12 obtained $t_{\text {observed }}=2.60>$ $\mathrm{t}_{\mathrm{tab}}=1.75$ at the significance level $\alpha=0.05$. Thus, Ha said that the existence of a significant relationship between parenting parents towards gross motor skills of students 
was accepted, consequently $\mathrm{H}_{0}$ was rejected. This finding concludes that the better the parenting score, the higher gross motor skills.

Parenting is an overall interaction between parents and children, where parents provide encouragement for children by changing behavior, knowledge, and values that are considered most appropriate for parents so that their children can be independent, grow and develop healthily and optimal, have confidence, have curiosity, are friendly and are oriented to success.

Based on the calculation results obtained the correlation coefficient obtained results $\mathrm{R}=0.584$ and $\mathrm{F}_{\text {observed }}=6.65>\mathrm{F}_{\text {table }}=3.68$ at the significance level $\alpha=$ 0.05 . It can be concluded, that the multiple correlation coefficient obtained in this study is significant. This finding accepts $\mathrm{Ha}$, namely the existence of a jointly significant relationship between the playing environment and parenting parents towards gross motoric skills of students. Consequently, $\mathrm{H}_{0}$ is rejected. a child's motor skills will develop with several things that influence it such as the nervous system maturity and also the development of the child's muscles. Apart from that, parenting parents and the environment are also factors that determine the child's motor development. True parenting from parents who are able to balance children's needs in terms of physical, psychological and learning needs will result in optimal child development, because the balance of the three things is crucial. The advantages in providing children's learning needs will cause children's motor development to be dissipated and vice versa. Parenting is also very necessary in the interaction and also the activities of children with the playing environment and place of residence. The social environment that is growing so rapidly and also the development of science and technology at this time is a threat to the growth of children both cognitive and motoric children.

\section{CONCLUSIONS}

Based on the results of the research described in the previous chapter, conclusions can be stated as follows: (1). There was a significant relationship between the playing environment towards the gross motoric ability of students with $t_{\text {observed }}=1.77>t_{\text {tab }}=1.75 ;(2)$. There is a significant relationship between parenting parents towards the gross motoric skills of students with $t_{\text {observed }}=2.60>t_{\text {tab }}=1.75$; (3) There is a significant relationship between the playing environment and parenting style towards the gross motoric skills of with $F_{\text {observed }}=6.65>F_{\text {table }}=3.68$.

\section{REFERENCES}

[1] Kamaruddin. "Psikologi Perkembangan". Selangor: Smart Print. 2011. pp. 23.

[2] Gusril, Toho. "Perkembangan Motorik Pada Masa Anak-Anak". Padang: UNP Press. 2004. pp13.

[3] Santrock. "Perkembangan Anak Jilid 1". Jakarta: Erlangga. pp. 54. 2007

[4] A. Eileen. "Profil Perkembangan Anak". Jakarta. Erlangga. pp. 23. 2010
[5] Mulyasa. "Manajemen PAUD". Bandung: PT Remaja Rosdakarya. Pp. 27. 2012

[6] Sugiyono. "Metode Penelitian Kuantitatif dan Kualitatif". Bandung: Alfabeta. pp. 9. 2014

[7] Gusril. "Model Perkembangan Motorik". Padang: UNP Press. 2008. Pp. 21. 